\title{
The Impact of AIDS on Birth Control
}

According to the Population Reference Bureau, the world population is growing at a rate of over 70 million per year, a figure comparable to the population of reunified Germany and larger than those of the UK and France. Every month, about 6.6 million people join the world population, while the weekly rate reaches 1.5 million. About $99 \%$ of the natural increase of the world population takes place in the less developed nations. Although alarming, these figures gave even more cause for concern a decade ago, when the growth rate was about 87 million per year (1990).

In 1999, the world population reached the 6 billion mark, the last billion having been added just 12 years after reaching 5 billion people. If the growth rate registered in the 90s had remained steady in the following decade, the planet's population would reach 7 billion in 7 years, by the year 2011, or shortly before. However, thanks to the birth control measures being taken in China and other countries, particularly India, whose population is already over one billion, and which combined with China contains over $40 \%$ of the world's total, we will reach the 7 billion mark a few years later. That extended interval will give the governments of developing nations more time to satisfy the basic needs of the over one billion people expected to be born in the next decade.

The population of Brazil, a continental country, was just 12 million in 1900, four hundred years after its discovery, and after that the population doubled in just thirty years thanks to obligatory vaccinations and improved sanitation in major cities. By 1970, Brazilians could boast that they were 90 million strong, a population twice that of France. The Brazilian population, which in 1970 showed a marked gap between rich and poor, with the poor in the majority, has doubled again in the last thirty years, reaching nearly 180 million. While the rich used family planning to limit the number of descendants sharing their wealth, the poor continued to have large families. This contributed to an explosion in the number of dispossessed, including the landless, the homeless, the foodless, the jobless, the healthless, the unclothed, the unshod and the uneducated. They lack everything except children. An illiterate 15-year-old serving a 100-year jail sentence who is not even allowed out of prison can still father as many children as he wants. There are so many people without food that the campaign to stamp out hunger is the main objective of Brazil's present administration, which provides school meals to over 30 million Brazilian children.

In the past, populations grew rapidly in times of plenty, but growth slowed and even began to shrink during wars and epidemics. Wars were inspired by religious and ideological disputes, and epidemics by environmental changes that fostered the spread of disease in large urban centers. The advances of science and particularly medicine have helped reduce the human mortality rate, thanks to the development of vaccines and antibiotics and an increase in farm production that helps feed the multitudes that now live in the planet's major cities. Despite this progress, Malthus's prediction that food production would not keep pace with the needs of the growing population is gaining credibility in light of the number of starving people in the developing world. There, population growth is still outstripping the ability to produce food, which obliges poor countries to obtain unpayable loans to buy food for children brought into this world irresponsibly in the absence of efficient family planning programs.

In the 1980s, when world population growth estimates were projected for the next millennium, no further epidemics that could affect the growth of populations in poor countries were predicted, much less wars like the major conflagrations of the past, which killed millions of individuals in the prime of life. In the early 1990s, however, less than a decade after the discovery of HIV, a virus unlike any that infectologists had ever encountered, some of the more pessimistic epidemiologists feared that AIDS would be the worst epidemic humankind has ever faced, as this sexually transmissible virus killed its victims in a short period of time by destroying the immune system. However, the 
more optimistic argued that the epidemic would be restricted to homosexuals and drug abusers, the two major risk groups identified at the time, and therefore would be restricted predominantly to males whose elimination could not possibly affect population growth. This optimistic view would soon disappear as the epidemic spread in Africa, a continent where heterosexual relations characterize the transmission of the virus and the victims are primarily women. In South Africa, the prevalence of HIV in women attending prenatal clinics jumped from $1 \%$ to $22 \%$ between 1990 and 1998. In Kwa-Zulu Natal province, the prevalence of the virus in pregnant women reached $33 \%$. All told, 4.7 million people have been infected with the AIDS virus in that country since the epidemic began. In Kenya, 2.5 million Kenyans, or one in six, have been infected. In Pumwani, a Nairobi slum, $90 \%$ of all prostitutes are HIV positive. It is estimated that over $70 \%$ of the world's HIV/AIDS sufferers are located in Africa. In Botswana, Lesotho, Swaziland and Zimbabwe, over $30 \%$ of the population are HIV positive. Africa has five of the six largest epidemics, the largest being in South Africa and the third largest in Nigeria. Of all the countries with major AIDS epidemics, the only one outside of Africa is India.

One consequence of the epidemic's impact on women of reproductive age has been an increase in the maternal mortality rate. In Malawi, the number has grown from 620 to 1,120; and in Zimbabwe, from 283 to 695 per 100,000 live births. Mortality due to AIDS among people of reproductive age (15 to 50) has increased dramatically in these two countries over the past ten years $-75 \%$ in Malawi and $150 \%$ in Zimbabwe.

The impact of the AIDS epidemic on population growth is not restricted to a higher mortality rate among people old enough to procreate and among unconceived and unborn children. It also changes the sexual habits of the non-contaminated population, which avoids promiscuity and demands the use of condoms. Even in countries like Brazil, where the Roman Catholic Church has a major influence on the Health Ministry, governments have been forced to go against church teachings and encourage the use of condoms through the mass media. Brazil has also reluctantly launched a family planning campaign that is also based on the practice of safe sex.

In its most recent survey, the UN World Population Prospects (2002), the UN estimates that the world population in 2050 will be 400 million smaller than it would have been without the decline in fertility and AIDS-related mortality, particularly in Africa. It is more than a little ironic that the AIDS epidemic has helped force the countries that were most reluctant to implement family planning policies to preach the virtues of responsible paternity and maternity. These countries were the ones whose populations were growing the fastest, crowding together in large slums on the outskirts of urban centers, creating ideal conditions for HIV to spread.

The world's painful experience with AIDS demonstrates that if science finds a way of overcoming this disease, as it has done with other epidemics, nature will find new ways to overcome ecological imbalances due to the overpopulation and monoculture that characterize most of the human race on this planet, thereby ensuring biodiversity, without which the human race itself would become an endangered species.

$$
\begin{gathered}
\text { Elsimar Coutinho } \\
\text { President of Brazilian Society of Endocrinal } \\
\text { Ginecology }
\end{gathered}
$$

